\title{
IBADAT, THE BODY AND IDENTITY: ISLAMIC RITUALS AND THE CONSTRUCTION OF MUSLIM IDENTITY
}

\author{
Medhy Aginta Hidayat \\ Department of Sociology, Trunojoyo University Madura \\ Email: medhy.hidayat@gmail.com
}

\begin{abstract}
This library-based theoretical paper examines three types of Islamic rituals or ibadat, that is salat, sawm and hajj, to understand the important of embodied rituals in the construction of Muslim identity. By utilizing several key theoretical ideas including Durkheim's Sacred and Profane, Bell's ritual and ritualization, and Whitehouse's modes of religiosity, this paper corroborates the previous findings in the religious and sociological studies that the body plays an important role for the construction of identity, including religious identity such as Muslim identity. This embodied or ritualized body, with its characteristics of formality, fixity, and repetition, constructs, upholds, enforces and maintains Muslim identity through its rituals of salat, sawm and hajj.
\end{abstract}

Keywords: identity, religious identity, embodied identity, Muslim identity, ritualization

\section{Introduction}

This paper examines the role of Islamic rituals in the construction of Muslim identity. Specifically, three types of Islamic rituals or ibadat are analyzed in this paper: salat, sawm and hajj. These three types of Islamic rituals are chosen deliberately as an explicit example of the embodied rituals in Islam. Catherine Bell's ideas of ritual and ritualization, and Harvey Whitehouse's concept of the modes of religiosity will be utilized as a frame of analysis. The first section of this paper reviews the sociological concept and definition of religion, and especially the important role of the Sacred and the Profane in religion. The second section specifically discusses Bell's conceptual thoughts of ritual and ritualization. The third section focuses on the dimensions of Islamic rituals and its relationship to the concept of identity. Finally, the fourth section analyzes the dynamic role of Islamic rituals in the construction of Muslim identity by using ritual and ritualization theory, and modes of religiosity theory as a means of analysis.

\section{Theoretical Frameworks}

\section{Durkheim's Religion: The Sacred and the Profane}

It seems that almost every religious scholar has his or her own definition of "religion." In this paper, religion will be defined by following Durkheim's sociological definition of 
religion. According to Durkheim in his famous book The Elementary Forms of Religious Life (1912), religion is understood as a "unified system of beliefs and practices relative to sacred things, that is to say, things set apart and forbidden - beliefs and practices which unite into one single moral community called a Church, all those who adhere to them" (Durkheim, 44). Durkheim's definition of religion emphasizes the importance of religious system of belief and practices, and the role of religious institutions - especially Churches - as "moral community" which acts to maintain the existence of society.

His functionalist view of religion also gives religious institutions higher levels of position than those of religious individuals. This is mainly because religion is "first and foremost a system of ideas by means of which individuals imagine the society of which they are members and the obscure yet intimate relations they have with it" (Durkheim, 227). In a more anthropological term, Durkheim's ideas of religion might be compared to Clifford Geertz's definition of religion. According to Geertz's explanation in his anthropological book The Interpretation of Cultures: Selected Essays (1993), a "religion is (1) a system of symbols which acts to (2) establish powerful, pervasive, and long-lasting moods and motivations in men by (3) formulating conceptions of a general order of existence and (4) clothing these conceptions with such an aura of factuality that (5) the moods and motivations seem uniquely realistic" (Geertz, 90). In some degree, Geertz's symbolic definition of religion which placed its central conception in the face of "general order of existence," as a foundational element of any religious society seems related to Durkheim's definition of religion. From my point of view, Durkheim's definition of religion which focuses on the role of religious institutions and its social functions can be usefully utilized as a departure point to understand the role of religious rituals in the construction of identity, more specifically a group identity (Islam or Muslim as a group of people) in a society.

Furthermore, Durkheim describes religion in terms of beliefs and rites. The first are ideas, concepts, values, and states of opinion, while the second are particular modes of action in the religious realm (Durkheim, 34). According to Durkheim, "rites are rules of conduct that prescribe how man must conduct himself with sacred things" (Durkheim, 38). For Durkheim, rites are particular ways of dealing in thought and action with the fundamental dichotomy of the Sacred and the Profane. The Sacred can be understood as something that is protected and isolated by prohibitions. Meanwhile, the Profane are something to which the prohibitions are applied and that must keep a distance from what is sacred (Durkheim, 38). In Durkheim's view, furthermore, the Sacred is far from being synonymous with the divine. It means that not only gods and spirits can be sacred, but also things like rocks, trees, pieces of 
wood, in fact anything can be sacred. In this sense, for what makes something sacred is not that it is somehow connected to the divine, but that it is the subject of a prohibition that sets it radically apart from something else, which is itself made something profane. Moreover, Durkheim conceded that "religious and profane life cannot coexist in the same space" (Durkheim, 312). Sacredness requires that special locations be set aside for religious rituals: the places where the ritual objects are stored when not in use, which are forbidden to profane persons. Accordingly, Durkheim also accepted that "religious and profane life cannot coexist in the same time" (Durkheim, 313). Sacredness also requires that special times be set aside for religious rituals. Thus, for example, the everyday activities of hunting, fishing and sporting must be suspended during the acts of religious ceremonies.

The ideas of "the Sacred and the Profane," especially the Sacred/Profane place and the Sacred/Profane time, are also elaborated in Mircea Eliade's work The Sacred and the Profane: The Nature of Religion (1982). He begins his finding by saying that "the sacred and the profane are two modes of being in the world, two existential situations assumed by man in the course of his history" (Eliade, 14). Eliade claims that, whereas for non-religious man the spatial aspect of the world is basically experienced as uniformly neutral, for religious man it was experienced as non-homogeneous, partly sacred and partly not. In particular, religious man experienced the world as having a sacred centre and sought to live there. The major differentiation of space for religious man was that between cosmos (an ordered world) and chaos (a disordered world). Traditional societies understood their own territory as cosmos, a world created out of primordial chaos by their gods, with surrounding territory remaining as chaos.

Eliade also stated that for religious man there were two types of time, chairos (sacred time) and chronos (profane time) (Eliade, 45). The former, for example, is experienced in religious festivals, while the latter in ordinary daily life. By contrast, modern, non-religious man does not experience sacred time. He or she has his periodic celebrations, but they are not experienced as sacred, as involving contact with the divine. However, even though both of these scholars discussed the same topic, it seems that Eliade's theory of the Sacred and the Profane, especially his ideas of the sacred place and sacred time, goes in a different direction from Durkheim's ideas. For me, Durkheim's ideas of the Sacred and the Profane are more likely to be applied for the Islamic rituals. Hence, for the purpose of this paper, I will use Durkheim's conceptual framework of the Sacred and the Profane as a means of analyzing of the ritual and ritualization strategy in the construction of Muslim identity. 


\section{Bell's Ritual and Ritualization}

Theoretical explanations of ritual generally regard it as action and distinguish it from the conceptual aspects of religion, such as beliefs, creeds, symbols, and myths. In her book Ritual Theory, Ritual Practice (1992), Bell clearly stated that "beliefs, creeds, symbols, and myths emerge as forms of mental content or conceptual blueprints: they direct, inspire, or promote activity, but they themselves are not activities" (Bell, 19). Meanwhile, ritual, like action, will act out, express, or perform religious conceptual orientations. Ritual is a means by which "collective beliefs and ideals are simultaneously generated, experienced, and affirmed as real by the community" (Bell, 20). In other words, ritual is the primary means by which individual perception and behavior are socially appropriated or conditioned.

In the context of social individuals' conditioning process, Bell suggests what she called "ritual mastery." According to her, ritual mastery is the ability "to (1) take and remake schemes from the shared culture that can strategically nuance, privilege, or transform, (2) deploy them in the formulation of a privileged ritual experience, which in turn (3) impresses them in a new form upon agents able to deploy them in a variety of circumstances beyond the circumference of the rite itself" (Bell, 116). As a consequence, ritual mastery implies that ritual can exist only in "the specific cultural schemes and strategies for ritualization (i.e., for the production of 'ritualized' practices) embodied and accepted by persons of specific cultural communities" (Bell, 107).

Meanwhile, according to Bell, "ritualization is a way of acting that is designed and orchestrated to distinguish and privilege what is being done in comparison to other, usually more quotidian, activities" (Bell, 74). As such, ritualization becomes a matter of various culturally specific strategies for setting some activities distinct from others, for creating and privileging qualitative distinctions between the 'Sacred' and the 'Profane,' and for ascribing such distinctions to realities thought to transcend the powers of human actors. Furthermore, intrinsic to ritualization are strategies for differentiating itself - to various degrees and in various ways - from other ways of acting within any particular culture. At a more complex level, it is a way of acting that "specifically establishes a privileged contrast, differentiating itself as more important or powerful" (Bell, 90).

According to Bell, the strategies of ritualization are particularly rooted in the body, specifically, the interaction of the social body within a symbolically constituted spatial and temporal environment (Bell, 93). She conceded that "the implicit dynamic and 'end' of ritualization can be said to be the production of a "ritualized body'" (Bell, 98). A ritualized 
body is thus a body invested with a sense of ritual. Following Foucault, Bell accepts that the body is "the place where the minute and local social practices are linked up with the large scale organization of power" (Bell, 202). Ritualization, thus is a "central way that power operates; it constitutes a political technology of the body" (Bell, 202). As a strategy for the constitution of power relations to the socialized agent, ritualization involves two basic dimensions. The first dimension is that of the dynamics of the social body, its projection and embodiment of a structured environment. The second dimension is that of the ritual construction of power which involves dynamics power relations constituted by ritualization that also empower those who may at first appear to be controlled by them (Bell, 207). Bell's conceptual ideas of ritual and ritualization, for the purpose of this paper, will be very useful and important as a means of analysis of how Muslim individuals exercise Islamic rituals, such as salat, sawm, and hajj, in order to construct their own Muslim identity.

\section{Islamic Rituals or Ibadat and the Concept of Identity}

According to Caesar Farah in her book Islam: Beliefs and Observances (1994), the Five Pillars of Islam (arkan al Islam) are five basic acts in Islam, considered obligatory by believers, and are the foundation of Muslim life (Farah, 23). The Five Pillars of Islam are shahada, salat, zakat, sawm, and hajj. The Qur'an presents them as a framework for religious act of worship or ibadat and a sign of commitment to the faith. These ibadat can also be seen as the Islamic basic rituals. Due to the scope of this paper, only salat, sawm and hajj, viewed as the primary embodied Islamic rituals (that is mainly using the body), that will be discussed and analyzed as a central means of Muslim identity construction. It should be noted as well that regarding these acts of Islamic worships, not all Muslims will do this ibadat in their daily life. However, as long as they do accept and embrace Islamic way of life and way of conduct, they will still be considered as Muslims in the majority of Muslim society. Meanwhile, Muslim individuals who regularly exercise these ibadat in their daily life will be considered more pious Muslims and thus strengthen their Muslim identity. Below is a very brief description of these three Islamic rituals or ibadat: salat, sawm, and hajj:

Salat (five times daily prayers)

Salat is the Islamic prayer. Salat consists of five daily prayers: Fajr (dawn), Dhuhr (noon), Asr (afternoon), Maghrib (evening), and Isha' (night) (Farah, 24). The Fajr prayer is performed before sunrise, Dhuhr is performed in the midday after the sun has surpassed its 
highest point, Asr is the evening prayer before sunset, Maghrib is the evening prayer after sunset and Isha is the night prayer. All of these prayers are recited while facing the Kaaba in Mecca. Muslims must wash themselves before prayer, this washing is called wudu (or "purification"). The prayer is accompanied by a series of set positions including; bowing with hands on knees, standing, prostrating and sitting in a special position (not on the heels, nor on the buttocks) .

Sawm (fasting during the month of Ramadan)

Sawm or fasting is an obligatory act during the month of Ramadan. Muslims must abstain from food and drink from dawn to dusk during this month, and are to be especially mindful of other sins. Fasting is necessary for every Muslim that has reached puberty (unless he/she suffers from a medical condition which prevents him/her from doing so). The fast is meant to allow Muslims to seek nearness and to look for forgiveness from God, to express their gratitude to and dependence on him, atone for their past sins, and to remind them of the needy. During Ramadan, Muslims are also expected to put more effort into following the teachings of Islam and to try to get along with fellow Muslims better. In addition, all obscene and irreligious sights and sounds are to be avoided (Farah, 27).

$\boldsymbol{H a j j}$ (the pilgrimage to Mecca at least once in a lifetime)

Hajj is a pilgrimage that occurs during the Islamic month of Dhu al-Hijjah to the holy city of Mecca. Every Muslim is obliged to make the pilgrimage to Mecca at least once in his or her life. When the pilgrim is around $10 \mathrm{~km}$ from Mecca, Muslims must dress in Ihram clothing, which consists of two white sheets. Both men and women are required to make the pilgrimage to Mecca. After a Muslim makes the trip to Mecca, he/she is known as a hajj/hajja (means one makes the pilgrimage to Mecca). The main rituals of the Hajj include walking seven times around the Kaaba termed Tawaf, touching the Black Stone termed Istilam, traveling seven times between Mount Safa and Mount Marwah termed Sa'yee, and symbolically stoning the Devil in Mina termed Ramee. The pilgrimage, or the hajj, is honored in the Muslim community. The Hajj should be an expression of devotion to God, not a means to gain social standing (Farah, 28). The believer should be self-aware and examine his or her intentions in performing the pilgrimage. This should lead to constant striving for self-improvement. 


\section{Burke's Concept of Identity}

In his book Identity Theory (2009), Peter Burke wrote that identity is generally used to define and describe an individuals' sense of self, group affiliations, structural positions, and ascribed and achieved statuses. Identity results from internal subjective perceptions, self reflection and external characterizations. Contrary to earlier understandings of identity as fixed and immutable, today identity is more often considered as an evolving process of "becoming" rather than simply of "being". Individual identity then can shift over time, due to personal experiences and larger social changes (Burke, 33). Moreover, identity attempts to link the individual conception of self and the larger social structure within which the individual thinks and acts. However, these approaches to identity vary in their emphases on social structure, on the one hand, and the processes and interactions through which identities are constructed, on the other (Burke, 2003). The structural approach relies on the concept of role identities in analyzing individuals' self-conceptions, behaviors, and social relations with others. The second approach highlights on-going processes of identity construction, selection, and negotiation (Burke, 112).

Meanwhile, a social identity is based on a person's identification with a social group. A social group is a set of individuals who share the view that they are members of the same social category. Religious identity, in this sense, can be viewed as a type of social identity. Having a particular religious identity means being like others in the group and seeing things from the group's perspective. It is assumed that religious individuals as group members think alike and act alike. Thus, there is uniformity in thought and action in being a religious group member. Individuals do not have to interact with other group members in order to think and act like the group. Simply identifying with the religious group is enough to activate similarity in perceptions and behavior among group members (Burke, 118). Having one's religious identity as a group member verified activates a sense of belongingness and raises one's selfworth. When one is a member of a religious group and is similar to others in thought and action, one will receive recognition, approval, and acceptance from other group members, thus verifying their religious identity as a group member; and in turn, they will experience positive feelings (Burke, 121). Burke's ideas of social and religious identity are very useful to understand deeply the meaning and dynamic of identity construction process. However, as we will see in the analysis section, it might be false to just concede that religious identity will create uniformity in thought and action among its members. 


\section{Theoretical Analysis}

\section{Embodied Islamic Rituals and Muslim Identity}

According to Bell, there are three characteristics of ritual and ritualization: formality, fixity, and repetition (Bell, 91). Formality, for Bell, is a process of embellishment of ritual power. Fixity, of times and places of ritual activities, as well as the exact gestures to be enacted, is a means of creating authoritative modeling of ritual. Meanwhile, repetition is a process of redundancy of certain ritual acts (Bell, 92). Following this scheme, salat, sawm and hajj, as acts of worship or ibadat, also have certain characteristic of rituals.

First of all, the performance of salat is considered centrally important in Islam (Mahmood, 123). Salat should be executed correctly. The correct execution of salat depends on the following elements: "(a) an intention to dedicate the prayer to God; (b) a prescribed sequence of gestures and words; (c) a physical condition of purity; and (d) proper attire" (Mahmood, 123). Furthermore, as discussed above in the section of Islamic ritual, salat - as a religious act of worship or ibadat - consists of five times daily prayers (this mainly as a character of "repetition" in ritual), facing the Kaaba, and the actors must wash themselves before prayer (as a character of "formality" in ritual). The prayer is also accompanied by a series of set positions including; bowing with hands on knees, standing, prostrating and sitting in a special position (as a character of "fixity" in ritual).

Moreover, the issue of punctuality of time in salat also entails more than the simple use of an alarm clock. Instead, it encompasses an entire attitude one cultivates in order to create the desire to pray. The desire to pray is thus not natural, but it must be created through a set of disciplinary acts. That is to say, desire in this model is not the antecedent to, or cause of, moral action, but its product (Mahmood, 126). In other Islamic ritual, sawm, Muslims are ordered to abstain from food and drink from dawn to dusk during the month of Ramadan (mainly as a character of "fixity" in ritual). Finally, in the practice of hajj, there are several rituals including walking seven times around the Kaaba, touching the Black Stone, traveling seven times between Mount Safa and Mount Marwah, and symbolically stoning the Devil in Mina (all of these are a character of "fixity" in ritual).

Salat, sawm and hajj, thus become embodied ritual acts which significantly differentiate Muslims and non Muslims, how to be and to act as Muslims, and finally what is actually the identity of Muslims. Every Muslim should be able to comprehend this "ritual mastery." Outward bodily gestures and acts (such as salat or wearing the veil) are indispensable aspects of the Islamic pious identity in two senses. First, that the self can acquire its particular form only through the performance of the precise bodily enactments. 
Second, that the prescribed bodily forms are necessary attributes of the self (Mahmood, 133). In this sense, embodied Islamic rituals become a primary means of social control for Muslim to define their own religious identity.

Regarding the ritualization concept, Islamic rituals such as salat, sawm and hajj also depict Bell's criteria of ritualization. According to Bell, "ritualization is a way of acting that is designed and orchestrated to distinguish and privilege what is being done in comparison to other, usually more quotidian, activities" (Bell, 74). In this light of ritualization strategy, we can see that salat, sawm and hajj have several distinctive ways of acting that distinguish and privilege them from other mundane activities. For example, in salat, there is a series of specific positions such bowing with hands on knees, standing, prostrating and sitting in a special position (not on the heels, nor on the buttocks). However, these positions become "Sacred" positions only in the act of salat, while they are considered usual or casual positions in other "Profane" activities such as in play or sport. Another ritualization strategy occurs in the act of sawm when Muslims are prohibited to eat and drink from dawn to dusk during Ramadan. In other months, Muslims are free to eat and to drink during the whole days and nights. This 'privileging act' during Ramadan then makes sawm a special act of eating and drinking with special religious meaning for Muslims. The same case of ritualization process also applies to the act of hajj. Hajj is a pilgrimage that occurs during the Islamic month of Dhu al-Hijjah to the holy city of Mecca. During the act of hajj, for example, every Muslim must dress in the same Ihram clothing, which consists of two white sheets, with no difference in their statuses, positions and backgrounds. These acts are in fact creating and privileging a qualitative distinction between the 'Sacred' clothing and the 'Profane' clothing as an instance of certain acts of traveling or trips with religious meaning.

In ritual and ritualization - "as practices that act upon the actions of others, as the mute interplay of complex strategies within a field structured by engagements of power, as the arena for prescribed sequences of repetitive movements of the body that simultaneously constitute the body, the person, and the macro- and micro networks of power" (Bell, 204) we can see a strategy of power relation among rituals agents. Moreover, ritualization is indeed "a strategic play of power, of domination and resistance, within the arena of the social body" (Bell, 204). In these terms, it is possible to see different ways of religious act or ibadat as a kind of resistance to the dominant power in Islamic rituals. For example, in salat, even though the main body gestures or movements are almost similar everywhere in any Muslim societies, there is quite different way of acts between the Middle Eastern Muslims and the 
South Eastern Asian Muslims. More specifically, these different gestures and positions can be seen in the act of bowing (with or without hands on knees) known as ruku', and in the act of sitting in a special position (while the Middle Eastern Muslims tend to sit on the heels, the South Eastern Asian Muslims sit on the buttocks).

Another clearer example of the play of power in Islamic rituals can be found in some parts of Gowa, Celebes Island, Indonesia. In Gowa, there is a well-known traditional practice of poor Muslims who do hajj not by making pilgrimage to the holy city of Mecca but to a mountain named Bawakaraeng near Gowa. While still maintaining the main rituals of the hajj such as walking seven times around the Kaaba, touching the Black Stone, traveling seven times between Mount Safa and Mount Marwah, and symbolically stoning the Devil in Mina, these "Bawakaraeng Hajj," conduct their rituals in their own local places and terms (Pabbajah, 2011). In this light, it can be conceded that the Islamic rituals and ritualization are thus also concerned with the dynamic of distinguishing different and local religious identities, ordering social differences, and controlling the contention and negotiation involved in the appropriation of religious symbols and acts (Bell, 130). As a consequence, in fact there are also a range variety of differences of identities among Muslims. In other words, Muslim identity construction, when it is viewed from the perspective of rituals and ritualization, has resulted in the formation of multi-forms of Muslim identities.

With regards to the idea of the modes of religiosity, the ideas of "doctrinal" and "imagistic" types of religiosity as presented by Harvey Whitehouse can be utilized to analyze the case of Islamic rituals and the construction of Muslim identity. According to Whitehouse in his book Modes of Religiosity: A Cognitive Theory of Religious Transmission (2004), there are two different modes of religiosity: doctrinal and imagistic. The doctrinal mode of religiosity is a type of modes of religiosity in which ritual action tends to be highly routinized, facilitating the storage of elaborate and conceptually complex religious teachings in semantic memory, but also activating implicit memory in the performance of most ritual procedures. These cognitive features are linked "to particular social morphology, including hierarchical, centralized institutional arrangements, expansionary potential, and dynamic leadership" (Whitehouse, 65).

Furthermore, the doctrinal mode of religiosity consists of a suite of mutually reinforcing features. When these features coalesce, they tend to be robust historically and may last for a long period of time. For Whitehouse, at the root of all this is "a set of cognitive causes deriving from the ways in which frequently repeated activities and beliefs are handled in human memory" (Whitehouse, 70). Meanwhile, the imagistic mode of religiosity is a type 
of modes of religiosity in which the sorts of practices that lead to the coalescence of imagistic features, according to Whitehouse, are invariably low frequency. The imagistic modes of religiosity are also, without exception, highly arousing. Generally, the doctrinal mode of religiosity tends to emphasize the uniformity and the centrality of religious acts, and the dynamic role of religious leaders. This mode of religiosity is more likely to spread highly in large scale of population. At the opposite, the imagistic mode of religiosity tends to be uniform, diffuse, and exclusive. The role of religious leaders is more likely to be passive or even, in some cases, absent. The imagistic mode of religiosity spread its religious values slowly and in a small scale of population. Examples of this mode of religiosity might include traumatic and violent initiation rituals, ecstatic practices of various cults, experiences of collective possession and altered states of consciousness, and extreme rituals involving homicide or cannibalism (Whitehouse, 70). Below is a table contrasting Whitehouse's two modes of religiosity:

\section{Modes of Religiosity - Doctrinal and Imagistic}

\begin{tabular}{|c|c|c|c|}
\hline No. & Variable & Doctrinal & Imagistic \\
\hline \multicolumn{4}{|c|}{ Psychological Features } \\
\hline 1. & Transmissive frequency & High & Low \\
\hline 2. & Level of arousal & Low & High \\
\hline 3. & $\begin{array}{l}\text { Principal memory } \\
\text { system }\end{array}$ & $\begin{array}{l}\text { Semantic shemas and } \\
\text { implicit scripts }\end{array}$ & $\begin{array}{l}\text { Episodic/flashbulb } \\
\text { memory }\end{array}$ \\
\hline 4. & Ritual meaning & Learned/acquired & Internally generated \\
\hline 5. & Techniques of revelation & $\begin{array}{l}\text { Rhetoric, logical } \\
\text { integration, narrative }\end{array}$ & $\begin{array}{l}\text { Iconicity, } \\
\text { multivocality, and } \\
\text { multivalence }\end{array}$ \\
\hline \multicolumn{4}{|c|}{ Sociopolitical Features } \\
\hline 6. & Social cohesion & Diffuse & Intense \\
\hline 7. & Leadership & Dynamic & Passive/absent \\
\hline 8. & Inclusivity/exclusivity & Inclusive & Exclusive \\
\hline 9. & Spread & Rapid, efficient & Slow, inefficient \\
\hline 10. & Scale & Large scale & Small scale \\
\hline 11. & Degree of uniformity & High & Low \\
\hline 12. & Structure & Centralized & Noncentralized \\
\hline
\end{tabular}


Based on this contrasting description of modes of religiosity, now we could analyze the role and place of salat, sawm and hajj, as the main embodied Islamic rituals, in Whitehouse's modes of religiosity.

Salat in the Modes of Religiosity

\begin{tabular}{|c|c|c|c|}
\hline No. & Variable & Characteristics & Descriptions \\
\hline \multicolumn{4}{|c|}{ Psychological Features } \\
\hline 1. & $\begin{array}{l}\text { Transmissive } \\
\text { frequency }\end{array}$ & High & $\begin{array}{l}\text { Five times daily prayers, } \\
\text { enable higher transfer of } \\
\text { Islamic teachings and } \\
\text { values }\end{array}$ \\
\hline 2. & Level of arousal & Relative & $\begin{array}{l}\text { It can be high when salat } \\
\text { is conducted as jama'ah } \\
\text { (as group), but relatively } \\
\text { low in individual salat }\end{array}$ \\
\hline 3. & $\begin{array}{l}\text { Principal memory } \\
\text { system }\end{array}$ & $\begin{array}{l}\text { Semantic shemas and } \\
\text { implicit scripts }\end{array}$ & $\begin{array}{l}\text { Mainly from the routine } \\
\text { exposures through } \\
\text { language, with long time } \\
\text { duration of memorizing } \\
\text { process }\end{array}$ \\
\hline 4. & Ritual meaning & Learned/acquired & $\begin{array}{l}\text { Salat is learned by every } \\
\text { Muslim since childhood, } \\
\text { not directly apprehended }\end{array}$ \\
\hline 5. & $\begin{array}{l}\text { Techniques of } \\
\text { revelation }\end{array}$ & $\begin{array}{l}\text { Rhetoric, logical } \\
\text { integration, narrative }\end{array}$ & $\begin{array}{l}\text { Using means such as } \\
\text { recitation of ayat on } \\
\text { Qur'an, religious } \\
\text { sermons, and religious } \\
\text { narrative }\end{array}$ \\
\hline \multicolumn{4}{|c|}{ Sociopolitical Features } \\
\hline 6. & Social cohesion & Relative & $\begin{array}{l}\text { It can be intense when } \\
\text { salat is conducted as } \\
\text { jama'ah (as group), but } \\
\text { relatively diffuse in } \\
\text { individual salat }\end{array}$ \\
\hline 7. & Leadership & Dynamic & $\begin{array}{l}\text { Islamic leaders, called } \\
\text { imam, in everyday salat } \\
\text { play significant role in } \\
\text { Muslim society }\end{array}$ \\
\hline 8. & $\begin{array}{l}\text { Inclusivity/exclusiv } \\
\text { ity }\end{array}$ & Inclusive & $\begin{array}{l}\text { Salat is for all Muslims, } \\
\text { no matter their sects or } \\
\text { beliefs (example: Sunni } \\
\text { or Shiite) }\end{array}$ \\
\hline 9. & Spread & Rapid, efficient & $\begin{array}{l}\text { Religious values are } \\
\text { spread rapidly and } \\
\text { efficiently due to the } \\
\text { high frequency of salat }\end{array}$ \\
\hline
\end{tabular}




\begin{tabular}{|c|l|l|l|}
\hline 10. & Scale & Large scale & $\begin{array}{l}\text { Salat give effects on } \\
\text { large scale of population } \\
\text { due to high frequency } \\
\text { and inclusive ways of } \\
\text { spreading }\end{array}$ \\
\hline 11. & $\begin{array}{l}\text { Degree of } \\
\text { uniformity }\end{array}$ & High & $\begin{array}{l}\text { Principally has similar } \\
\text { values, teachings, and } \\
\text { movements anywhere } \\
\text { and anytime }\end{array}$ \\
\hline 12. & Structure & Centralized & $\begin{array}{l}\text { The religious structure is } \\
\text { centralized due to the } \\
\text { importance role of } \\
\text { religious leaders }- \text { imam }\end{array}$ \\
\hline
\end{tabular}

Salat is thus more likely to be considered as a part of doctrinal mode of religiosity. This is because almost all of its psychological and sociopolitical features are match with the features of the doctrinal rather than the imagistic mode of religiosity.

Sawm in the Modes of Religiosity

\begin{tabular}{|c|l|l|l|}
\hline No. & \multicolumn{1}{|c|}{ Variable } & \multicolumn{1}{|c|}{ Characteristics } & \multicolumn{2}{c|}{ Descriptions } \\
\hline Psychological Features & $\begin{array}{l}\text { Transmissive } \\
\text { frequency }\end{array}$ & Relatively low & $\begin{array}{l}\text { Eventhough not as high } \\
\text { as salat, the frequency of } \\
\text { sawm also contribute to } \\
\text { the highly religious } \\
\text { values' transfers }\end{array}$ \\
\hline 2. & Level of arousal & Relatively low & $\begin{array}{l}\text { Relatively low because } \\
\text { sawm is a religious act } \\
\text { which is exercised } \\
\text { individually. }\end{array}$ \\
\hline 3. & $\begin{array}{l}\text { Principal memory } \\
\text { system }\end{array}$ & $\begin{array}{l}\text { Semantic shemas and } \\
\text { implicit scripts }\end{array}$ & $\begin{array}{l}\text { Mainly from the routine } \\
\text { exposures through } \\
\text { language, with long time } \\
\text { duration of memorizing } \\
\text { process }\end{array}$ \\
\hline 4. & Ritual meaning & Learned/acquired & $\begin{array}{l}\text { Sawm is learned by every } \\
\text { Muslim since childhood, } \\
\text { not directly apprehended }\end{array}$ \\
\hline 5. & $\begin{array}{l}\text { Techniques of } \\
\text { revelation }\end{array}$ & $\begin{array}{l}\text { Rhetoric, logical } \\
\text { integration, narrative }\end{array}$ & $\begin{array}{l}\text { Using means such as } \\
\text { recitation of } \text { ayat on } \\
\text { Qur'an, religious } \\
\text { sermons, and religious } \\
\text { narrative }\end{array}$ \\
\hline
\end{tabular}




\begin{tabular}{|c|c|c|c|}
\hline \multicolumn{4}{|c|}{ Sociopolitical Features } \\
\hline 6. & Social cohesion & Relatively intense & $\begin{array}{l}\text { As a religious act, sawm } \\
\text { gives relatively intense } \\
\text { impact for social } \\
\text { cohesion (sawm is a } \\
\text { social ritual) }\end{array}$ \\
\hline 7. & Leadership & Dynamic & $\begin{array}{l}\text { Islamic leaders, called } \\
\text { imam, play significant } \\
\text { role in the practice of } \\
\text { sawm (ex: deciding the } \\
\text { time of sawm) }\end{array}$ \\
\hline 8. & $\begin{array}{l}\text { Inclusivity/exclusiv } \\
\text { ity }\end{array}$ & Inclusive & $\begin{array}{l}\text { Sawm is for all Muslims, } \\
\text { no matter their sects or } \\
\text { beliefs (example: Sunni } \\
\text { or Shiite) }\end{array}$ \\
\hline 9. & Spread & Rapid, efficient & $\begin{array}{l}\text { Religious values are } \\
\text { spread rapidly and } \\
\text { efficiently due to the } \\
\text { large scale of population } \\
\text { who do sawm }\end{array}$ \\
\hline 10. & Scale & Large scale & $\begin{array}{l}\text { Sawm give effects on } \\
\text { large scale of population } \\
\text { due to its inclusive ways } \\
\text { of spreading }\end{array}$ \\
\hline 11. & $\begin{array}{l}\text { Degree } \\
\text { uniformity }\end{array}$ & High & $\begin{array}{l}\text { Principally has similar } \\
\text { values, teachings, and } \\
\text { rules anywhere and } \\
\text { anytime }\end{array}$ \\
\hline 12. & Structure & Centralized & $\begin{array}{l}\text { The religious structure is } \\
\text { centralized due to the } \\
\text { importance role of } \\
\text { religious leaders - imam }\end{array}$ \\
\hline
\end{tabular}

Like salat, sawm has its majority of features closer to the doctrinal mode of religiosity. However, due to its relatively low frequency of religious values' transmissions, sawm is less doctrinal than salat in terms of its efficiency in the modes of religiosity.

Hajj in the Modes of Religiosity

\begin{tabular}{|c|l|l|l|}
\hline No. & \multicolumn{1}{|c|}{ Variable } & \multicolumn{1}{|c|}{ Characteristics } & \multicolumn{1}{|c|}{ Descriptions } \\
\hline \multicolumn{2}{|l|}{ Psychological Features } & Relatively low & $\begin{array}{l}\text { This is mainly because } \\
\text { hajj is conducted only } \\
\text { once a year and only for }\end{array}$ \\
\hline 1. & $\begin{array}{l}\text { Transmissive } \\
\text { frequency }\end{array}$
\end{tabular}




\begin{tabular}{|c|c|c|c|}
\hline & & & well-living Muslims \\
\hline 2. & Level of arousal & Relatively high & $\begin{array}{l}\text { Because hajj involves } \\
\text { millions of people at the } \\
\text { same place and the same } \\
\text { time in Mecca }\end{array}$ \\
\hline 3. & $\begin{array}{l}\text { Principal memory } \\
\text { system }\end{array}$ & $\begin{array}{l}\text { Semantic shemas and } \\
\text { implicit scripts }\end{array}$ & $\begin{array}{l}\text { Mainly from the routine } \\
\text { exposures through } \\
\text { language, with long time } \\
\text { duration of memorizing } \\
\text { process }\end{array}$ \\
\hline 4. & Ritual meaning & Learned/acquired & $\begin{array}{l}\text { Hajj is learned by every } \\
\text { Muslim since childhood, } \\
\text { not directly apprehended }\end{array}$ \\
\hline 5. & $\begin{array}{l}\text { Techniques } \\
\text { revelation }\end{array}$ & $\begin{array}{l}\text { Rhetoric, logical } \\
\text { integration, narrative }\end{array}$ & $\begin{array}{l}\text { Using means such as } \\
\text { recitation of ayat on } \\
\text { Qur'an, } \\
\text { sermons, and religious } \\
\text { narrative }\end{array}$ \\
\hline \multicolumn{4}{|c|}{ Sociopolitical Features } \\
\hline 6. & Social cohesion & Relatively intense & $\begin{array}{l}\text { As a religious act, hajj } \\
\text { gives relatively intense } \\
\text { impact for social } \\
\text { cohesion (hajj is a social } \\
\text { ritual) }\end{array}$ \\
\hline 7. & Leadership & Dynamic & $\begin{array}{l}\text { Islamic leaders, called } \\
\text { imam, play significant } \\
\text { role in the practice of } \\
\text { hajj }\end{array}$ \\
\hline 8. & Inclusivity/exclusivity & Inclusive & $\begin{array}{l}\text { Hajj is for all Muslims, } \\
\text { no matter their sects or } \\
\text { beliefs (example: Sunni } \\
\text { or Shiite) }\end{array}$ \\
\hline 9. & Spread & $\begin{array}{l}\text { Relatively slow, } \\
\text { inefficient }\end{array}$ & $\begin{array}{l}\text { The spread is relatively } \\
\text { slow and inefficient due } \\
\text { to some factors such as } \\
\text { time and money }\end{array}$ \\
\hline 10. & Scale & Large scale & $\begin{array}{l}\text { Hajj give effects on } \\
\text { large scale of population } \\
\text { due to its inclusive ways } \\
\text { of spreading }\end{array}$ \\
\hline 11. & Degree of uniformity & High & $\begin{array}{l}\text { Principally has similar } \\
\text { values, teachings, and } \\
\text { rules anywhere and } \\
\text { anytime }\end{array}$ \\
\hline 12. & Structure & Centralized & $\begin{array}{l}\text { The religious structure is } \\
\text { centralized due to the } \\
\text { importance role of } \\
\text { religious leaders - imam }\end{array}$ \\
\hline
\end{tabular}


It might be conceded that hajj is the least doctrinal religious act in the modes of religiosity, due to its low frequency of transmission, high level of arousal and slowly religious spread.

Based on the analysis above, it can be accepted that salat, sawm and hajj, as a means of embodied Islamic rituals or ibadat, play an important role in the Islamic modes of religiosity, more specifically the doctrinal mode of religiosity. In this sense, it also can be concluded that Muslim identity is in fact mainly constructed, upheld, enforced and maintained through its rituals such as salat, sawm and hajj, which have characteristics of centralized, efficient, uniformized, and in large scale of population.

This finding, interestingly, is also in accordance with Bell's stand point that ritual tend to play an important role in societies that are (1) closed social groups with (2) restricted codes of linguistic and symbolic communication, in which (3) there is great emphasis on hierarchical position as opposed to personal identity and (4) yet a general social consensus still upholds the system (Bell, 178). In terms of identity construction, the modes of religiosity of Islam, which is doctrinal, thus tend to maintain the forms of Muslim identity as a more stable and persistent identity. However, according to the previous analysis of Islamic rituals and ritualization, it should be noted as well that there are different acts of worship in Islam. As a consequence, it could be concluded that there are actually different types of Muslim identities which are constructed through Islamic rituals such as salat, sawm and hajj. The construction of Muslim identity, yet embraces the same Islamic beliefs, creates different types of identities and never brings a single type of Muslim identity.

\section{Conclusion}

Muslim identity, from the ritual point of view, is an outcome of Islamic rituals and ritualization practices. Islamic rituals or ibadat, especially salat, sawm and hajj, have become an effective means of constructing Muslim identity through its highly embodying practices of religious values and teachings into embodied individual Muslims. Islamic rituals are also more likely perceived as a doctrinal, rather than imagistic in terms of its modes of religiosity. Finally, the construction of Muslim identity seems to be in the central point of power dynamic, in a strategic play of power, of domination and resistance, within the arena of the social body, yet embracing the same Islamic beliefs, creating different types of identities and never bringing a single type of Muslim identity. 


\section{Referensi}

Bell, C. (1992). Ritual Theory, Ritual Practice. New York. Oxford University Press.

Burke, P. J \& Stets. J. E. (2009). Identity Theory. New York. Oxford University Press.

Durkheim, E. (1912). The Elementary Forms of Religious Life. New York. The Free Press.

Eliade, M. (1982). The Sacred and The Profane: The Nature of Religion. New York, Harper Torchbook.

Farah, C. (1994). Islam: Beliefs and Observances (5th ed.). New York. Barron's Educational Series.

Geertz, C. (1993). The Interpretation of Cultures: Selected Essays. New York, Basic Books.

Mahmood, S. (2005). Politics of Piety: The Islamic Revival and the Feminist Subject. New Jersey, Princeton University Press.

Pabbajah, M. (2011). Haji Bawakaraeng: Resistensi Masyarakat Lokal di Sulawesi Selatan. Unpublished paper. The 11th Annual Conference on Islamic Studies, Bangka-Belitung, Indonesia.

Turner, V. (1967). "Betwixt and Between: The Liminal Period in Rites de Passage", in The Forest of Symbols: Aspects of Ndembu Ritual. New York. Cornell University.

Turner, V. (1969). The Ritual Process: Structure and Anti-Structure. London. Penguin.

Whitehouse, H. (2004). Modes of Religiosity: A Cognitive Theory of Religious Transmission. California, Altamira Press. 